BJHS: Themes 3:167-189, 2018. C British Society for the History of Science 2018. This is an Open Access article, distributed under the terms of the Creative Commons Attribution licence (http://creativecommons.org/licenses/by/4.0/), which permits unrestricted re-use, distribution, and reproduction in any medium, provided the original work is properly cited.

doi:10.1017/bjt.2018.1 First published online 14 February 2018

\title{
Ideas, politics and practices of integrated science teaching in the global Cold War
}

\author{
KRISTIAN H. NIELSEN*
}

\begin{abstract}
During the Cold War, UNESCO played a major role in promoting science education across the world. UNESCO's Programme in Integrated Science Teaching, launched in 1969, placed science education at the heart of socio-economic development in all nations. The programme planners emphasized the role of science education in the development of human resources necessary to build a modern nation state, seeking to build a scientific and engineering mindset in children. UNESCO's interest in science education drew inspiration from early Cold War curriculum reforms in the United States, where scientists, psychologists and teachers promoted science education as a way to enhance the scientific and technical workforce and to counteract irrational tendencies. While US curriculum reformers were concerned about the quantity and quality of science teaching in secondary school, UNESCO wanted to introduce science as a topic in primary, secondary and vocational schools, promoting integrated science teaching as the best way to do this. From the outset, the term 'integrated' meant different things to different people. It not only entailed less focus on scientific disciplines and scientific method strictly defined, but also more on teaching children how to adopt a curious, experimental and engineering approach in life. By the end of the Cold War, UNESCO abandoned the idea of integrated science teaching, but it has a lasting legacy in terms of placing ways of teaching science to children at the heart of modern society.
\end{abstract}

'Scientific literacy is an essential element of modern life and must be introduced in the primary schools as part of the ABC of education. No meaningful preparation for the world of tomorrow can be made without science and technology.' At the planning meeting for UNESCO's Programme in Integrated Science Teaching, held in Paris on 17-19 March 1969, Stephen Oluwole Awokoya, director of UNESCO's Department of Science Teaching and Technological Education and Research, stressed the urgency of the task ahead for science teachers. ${ }^{1} \mathrm{He}$ also noted that the ferment of activities since the end of the Second World War had been so great that it aspired to 'a revolution in science teaching'. Integrated science teaching was an umbrella term that seemed promising for facilitating science improvement programmes in the developing countries. Integrated science teaching would use new teaching techniques to achieve many things: to provide children with a fundamental science-based understanding of the

* Centre for Science Studies, Aarhus University, 8000 Aarhus C, Denmark. Email: khn@css.au.dk.

1 Stephen Oluwole Awokoya, 'Opening address', in Planning Meeting for UNESCO's Programme in Integrated Science Teaching, Paris, 17-19 March 1969. Final Report, 30 June 1969, pp. 18-20, at http:// unesdoc.unesco.org/images/0001/000172/017244EB.pdf, accessed 14 November 2017. 
natural world, to introduce them to basic scientific thinking, to allow them to recognize that science forms part of contemporary society, and to encourage them to engage critically and experimentally with their environment to improve it. Awokoya announced that UNESCO, to implement such ambitious goals, would support integrated science teaching in all member states by launching its programme to promote the exchange of information, to extend technical services, to initiate and support experimental projects, and to arrange a series of integrated science teaching workshops.

Today, UNESCO's programme in Integrated Science Teaching, which ran from 1969 to 1990 , provides us with insight into how curriculum workers and science teachers around the world used and appropriated integrated science teaching. This paper places UNESCO's programme against the backdrop of the early Cold War reconstruction of science education in the United States and abroad. ${ }^{2}$ Based on archival material, as well as reports, conference proceedings and more, published during the course of the programme, the paper contributes to the historiography of science education and the development of the global Cold War. The paper's central thesis has three elements. First, UNESCO's Programme in Integrated Science Teaching drew inspiration from science curriculum reforms in the United States and elsewhere - what Awokoya called 'a revolution in science teaching' - but due to its emphasis on science education for development, it provided new ideas about the role of science education in society. Second, based on prevailing ideas about human resources, UNESCO's programme presented science education as a means to promote socio-economic development and to prepare children in the developing countries mentally and practically for the modern world, characterized by rapid advances and changes. Science education, like science, is never actually free of value and politics. Third, and finally, UNESCO's programme recommended adapting all innovations in science teaching to local needs and resources, which inspired diversity and even disagreement about the very idea of integrated science teaching. By the end of the Cold War, the ideological and political foundations of the programme had disintegrated.

\section{Science curriculum reforms in the early Cold War United States}

After the Second World War, curriculum reformers in the United States began to develop the 'revolutionary' science education projects that so enthused Awokoya and others. ${ }^{3}$ The reformers included scientists, teachers and administrators. Usually, a prestigious scientist acted as a spearhead. With the support of their professional organizations and often with financial backing from the National Science Foundation (NSF), these people launched many different national science curriculum projects, all aimed at strengthening pupils' understanding of the conceptual structure of the sciences and the process of scientific inquiry. Ambitions were high. Not only would the new curriculum

2 John L. Rudolph, Scientists in the Classroom: The Cold War Reconstruction of American Science Education, New York: Palgrave, 2002. See also George E. DeBoer, A History of Ideas in Science Education: Implications for Practice, New York: Teachers College Press, 1991.

3 Rudolph, op. cit. (2); Wayne W. Welch, 'Twenty years of science curriculum development: a look back', Review of Research in Education (1979) 7, pp. 282-306. 
provide science teachers with comprehensive and up-to-date information about the sciences, as well as a more accurate image of the nature of science, emphasizing tentativeness and process, but it would also offer inspiration for curriculum reformers in other countries. Immediate shortages of technical personnel spurred the movement, as well as the idea that science and technology are key drivers of wealth and health. ${ }^{4}$ The movement gained momentum due to perceived threats to national security stimulated by Cold War competition with the Soviet Union, culminating in the Soviet launching of the sputnik satellite in 1957, and by persistent claims that progressive education, as developed in the interwar years, had failed. ${ }^{5}$

Scientists were the prime movers of the reforms. During the Second World War, scientists and physicists in particular had helped the military to develop new weapons, logistical support and devices used for navigation, communication and remote sensing. After the war, they profited from their wartime experiences as they fostered a post-war, Big Science research culture defined by large-scale, goal-directed projects based on practical problem solving using sophisticated analytical tools. ${ }^{6}$ As scientists gradually realized the extent to which their knowledge and approaches were useful for overcoming a wide variety of different problems, they grew increasingly ambitious in extending their consultancy services to government agencies, industries and think tanks. At MIT, for example, scientists examined the threat of Soviet submarine attacks (Project Hartwell, completed in 1950) and the problem of Soviet jamming of Voice of America (Project Troy, completed in 1951). ${ }^{7}$ Both Hartwell and Troy ran as summer studies, bringing together experts from different disciplines who applied their knowledge to perform analyses of the problems at hand and to suggest new solutions.

In 1956, Jerrold Zacharias, an MIT physicist and member of the Science Advisory Committee of the Office of Defense Mobilization, proposed a science education project involving instructional films in physics to Harry C. Kelly, head of the Divisional Committee for Scientific Personnel and Education of the NSF. Zacharias and Kelly were both concerned about the lack of scientific and technical workers, and both were frustrated by the existing approaches to science education. Scientists, not educationalists, should design curricula and teaching materials for primary and secondary schools, they agreed. Zacharias easily received the funding (and more) required from the NSF and proceeded to organize what became known as the Physical Science Study Committee (PSSC). From his participation in Project Hartwell, Zacharias had learned that the most efficient way to inspire high-ranking and busy scientists to become involved was to organize a type of summer study, as well as that an engineering approach to

4 Sevan G. Terzian, “Adventures in science”: casting scientifically talented youth as national resources on American radio, 1942-1958', Paedagogica Historica (2008) 44, pp. 309-325.

5 Rudolph, op. cit. (2).

6 See, for example, Peter Galison and Bruce W. Hevly (eds.), Big Science: The Growth of Large-Scale Research, Stanford, CA: Stanford University Press, 1992; Daniel J. Kevles, 'Cold War and hot physics: science, security, and the American state, 1945-56', Historical Studies in the Physical and Biological Sciences (1990) 20, pp. 239-264.

7 On Project Troy see Allan A. Needell, “"Truth is our weapon”: Project TROY, political warfare, and government-academic relations in the national-security state', Diplomatic History (1993) 17, pp. 399-420. 


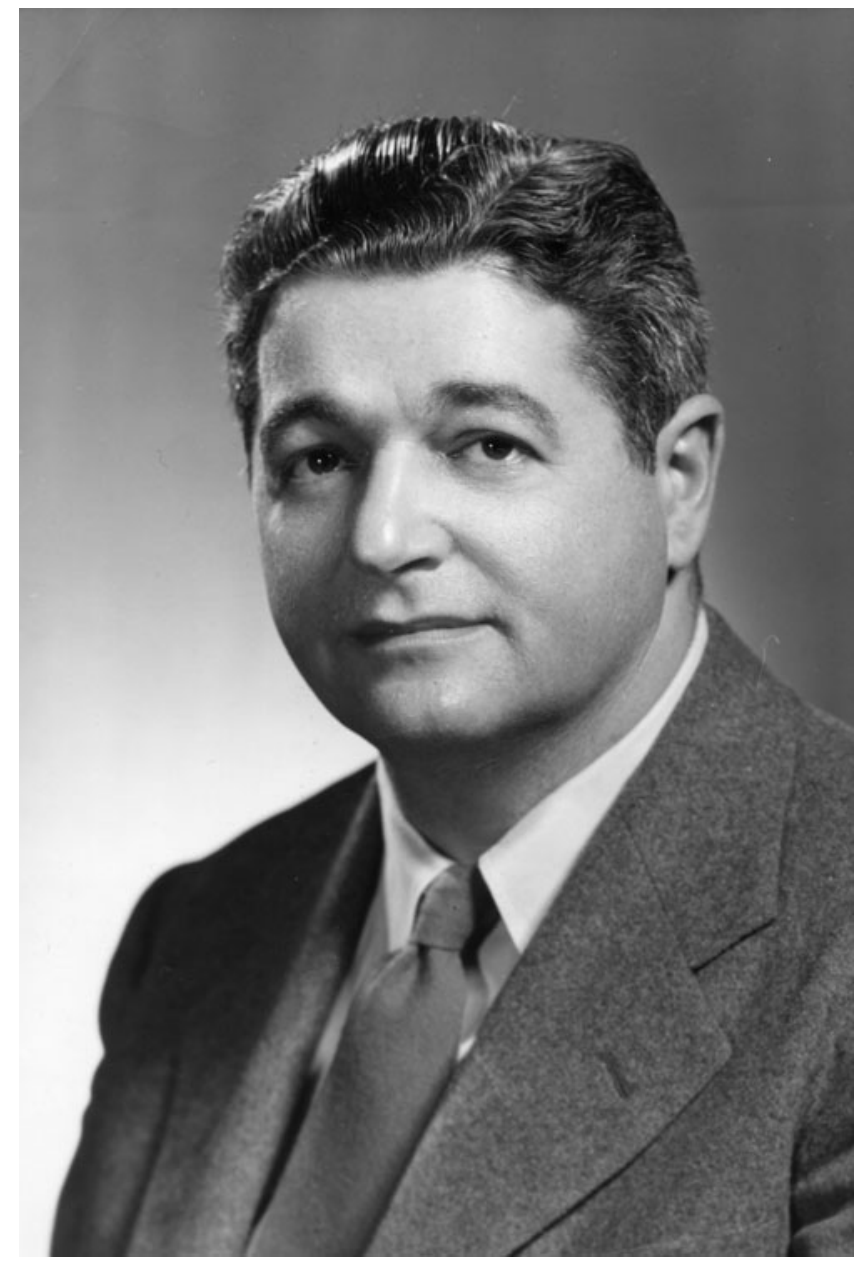

Figure 1. According to James Gleick, President John F. Kennedy once remarked that Jerrold Zacharias 'started a revolution in science teaching in the United States' (James Gleick, 'Jerrold R. Zacharias, Atomic Physicist, Dies', New York Times, 18 July 1986, available at www. nytimes.com/1986/07/18/obituaries/jerrold-r-zacharias-atomic-physicist-dies.html). Although he played a major role in early Cold War curriculum reforms, Zacharias was one of many scientists urging teachers to focus on basic conceptual structures in the sciences and hands-on excitement about real science. Source: AIP Emilio Segrè Visual Archives, Physics Today Collection.

science education, responding to paedagogical challenges with innovative teaching tools, would be preferable. ${ }^{8}$

The PSSC quickly developed much grander ambitions than merely producing a number of physics movies, although the film component remained an important part of PSSC's work well into the 1960s. All PSSC members agreed with Zacharias that the aim of pre-college science education was not simply to provide pupils with scientific

8 Rudolph, op. cit. (2), Chapter 4. 
information based on disciplinary and subdisciplinary knowledge specialization. They also envisaged much broader goals. First, science education ought to encourage children's rational and critical thinking. Most PSSC-ers would tie rationality to the natural sciences, the model of which was physical science. Learning about empirical methods and methods of reasoning in physics, therefore, would serve the larger purpose of counteracting irrational and science-sceptic tendencies in American culture. Second, reforming science education was a prerequisite for changing the public understanding of science and enhancing public perceptions of science. Science, from the PSSC's perspective, was not merely a body of knowledge but also, and perhaps more essentially, an inquiry process that required nurturing an inquiring frame of mind. Children, i.e. future citizens, needed to learn about these aspects of science in school. Third, by emphasizing the rational, existential and holistic features of science, the PSSC wanted to reinstate science at the very core of Western cultural thought. ${ }^{9}$

With lavish funding from the NSF - John L. Rudolph estimates 'well over \$200 million when all was said and done' - the PSSC produced a major new physics textbook, more than fifty physics movies, classroom laboratory materials and several shorter books to be used in physics teaching. ${ }^{10}$ The PSSC had an impact beyond physics education, partly because its efforts were aligned with prevalent ideas about national security and competitiveness. Thus it was easy to see the curriculum reforms of the PSSC as part of a national effort to train more working scientists and engineers for industry and the military. At the time, many interpreted the 1957 launch of sputnik as indicating the scientific and engineering superiority of the Soviet Union. David Kaiser has argued that physicists, many of whom were already engaged in curriculum development, used or 'spun' the sputnik crisis in their ongoing efforts to promote science education as crucial to national security. ${ }^{11}$ They were instrumental in passing the National Defense Education Act (NDEA) in Congress, although the data about the Soviet educational system that they themselves collected did not support a strong case for American inferiority with regard to science and engineering capabilities. ${ }^{12}$ The NDEA's core initiatives included programmes to improve science education, as well as foreign-language instruction. At a more general level, the NDEA was an attempt to define a new educational identity with a greater emphasis on national teaching standards as opposed to local ones, ultimately with a mixed impact. ${ }^{13}$

In line with David Kaiser's argument that physicists were deliberately exaggerating the 'manpower gap', John L. Rudolph's study of the PSSC indicates that its members were not terribly concerned with the shortage of working scientists and engineers. Rather,

9 Rudolph, op. cit. (2), Chapter 5.

10 John L. Rudolph, 'PSSC in historical context: science, national security, and American culture during the Cold War', American Association of Physics Teachers (2006), at www.compadre.org/portal/pssc/docs/ Rudolph.pdf, accessed 14 November 2017.

11 David Kaiser, 'The physics of spin: sputnik politics and American physics in the 1950s', Social Research (2006) 73, pp. 1225-1252.

12 Kaiser, op. cit. (11), pp. 1238-1239.

13 Kathleen Anderson Steeves, Philip Evan Bernhardt, James P. Burns and Michele K. Lombard, 'Transforming American educational identity after sputnik', American Educational History Journal (2009) 36, pp. 71-87. 
they wanted to address what they perceived as ideological threats to American culture, such as irrationalism, misconceptions about science and lack of public support for basic science. Many physicists had participated in wartime efforts to develop the atomic bomb and other military technologies. Their self-image, however, revolved around science as an essentially human and cultural endeavour, and they were determined to make a case for curiosity-driven scientific research. Although science would sometimes lead to practical applications related to health, prosperity and security, they argued, scientific research was much more than that. Science was the very key to modern civilization, with its emphasis on objective knowledge and reasoned argument. Thus science education could and should inform the entire curriculum. ${ }^{14}$

The PSSC demonstrated that scientists could (and should) be leading reformers in science education. In the wake of the PSSC followed the Biological Sciences Curriculum Study (BSCS) in 1958, the CHEM study in 1960, and many other US academic study committees or think tanks established regarding the subject of curriculum reform. ${ }^{15}$ Most of these groups boasted impressive lists of prestigious steering group members or consultants to lend credibility to their work. As psychologist Jerome Bruner, who was involved with the PSSC and other groups, later ironically recalled, 'no curriculum project of the first five years ... was worth its salt unless it could sport a Nobel laureate or two on its letterhead'. ${ }^{16}$ Although many saw the curriculum reform groups as one movement, and generally most reformers shared the basic ideas of the PSSC, some disagreement with respect to the scope and content of the reforms was expressed, for example, in disputes between mathematicians involved in the School Mathematics Study Group and physicists involved in the PSSC. ${ }^{17}$

For some scientists involved in the PSSC, trends of irrationalism represented another reason why science education should introduce children and young persons to rational thinking and sound judgement based on the best available evidence. These scientists were genuinely concerned about what we might call the 'science literacy deficit', as evidenced, for example, by rampant McCarthyism, with its anti-intellectual bent. In the early 1950s, Senator Joseph McCarthy had investigated some PSSC scientists, such as Jerrold Zacharias and Cornell physicist Philip Morrison. An anonymous article in Fortune magazine in 1954 identified Zacharias as member of a shadowy group known as ZORC - Z for Zacharias, O for J. Robert Oppenheimer, R for Isidor Isaac Rabi, and $\mathrm{C}$ for Charles Christian Lauritsen - who allegedly attempted to damage national security. Zacharias refused to cooperate with McCarthy's agents and worried that he might lose his job. ${ }^{18} \mathrm{He}$ was convinced that ideological hysteria and irrationalism

14 Rudolph, op. cit. (2), p. xx.

15 Laura Engleman (ed.), The BSCS Story: A History of the Biological Sciences Curriculum Study, Colorado Springs: BSCS, 2001; Glenn T. Seaborg, 'Forward from the CHEM study story', 3 February 1969, at www2. lbl.gov/Publications/Seaborg/chemStudy.htm, accessed 14 November 2017; Welch, op. cit. (3), pp. 285-289.

16 Quoted in Welch, op. cit. (3), p. 284.

17 On the disputes between mathematicians and physicists see Kristy Sorensen, 'Archives of American Mathematics Spotlight: the School Mathematics Study Group Records', Mathematical Association of America, undated, www.maa.org/the-school-mathematics-study-group-records, accessed 14 November 2017.

18 Charles Thorpe, Oppenheimer: The Tragic Intellect, Chicago: The University of Chicago Press, 2006, pp. 211-212. 
would be incompatible with science, defined as a free, open and rational endeavour. As sociologist of science Robert K. Merton argued in 1942, although science in the past had thrived in aristocratic societies, modern science, defined by universal truth criteria, open communication, rigorous policing of conflicts of interest and detached scrutiny of knowledge claims, would achieve its fullest measure of development in an open, democratic society. ${ }^{19}$ Science education, applied properly in the United States and elsewhere, would therefore be a way in which to diminish superstitions of all kinds and to prepare the foundations for more enlightened, liberal democracies worldwide. ${ }^{20}$

Whereas PSSC physicists stressed objective thinking, open-ended inquiry and nonauthoritarianism as the key goals of science education, indeed of all education, others were more genuinely interested in promoting science and technology for national security and prosperity. At the Woods Hole Conference in 1959, where many scientists and educators involved in the curriculum reforms met to discuss the new developments in science and mathematics teaching, most of the participants agreed that the United States needed more scientists and engineers to secure its foothold as the number one economic and ideological superpower in the world. To facilitate the flow of students directly from primary to secondary and tertiary programmes, science teaching had to provide students with fundamental ideas and specific content knowledge of the scientific disciplines as early as possible. Inspiring more students to aim for careers in science and engineering was the ultimate goal of science education, and the curriculum needed to reflect this. The solution to the problem, participants at Woods Hole agreed, was developing new curricula that would entice teachers to teach the conceptual structure of the discipline and to use inductive discovery as the appropriate mode of learning. ${ }^{21}$

The curriculum reforms initiated by PSSC and other groups were unprecedented in scope due to federal government funding, the involvement of working scientists and the widespread use of the new courses across the country. George E. DeBoer, in his historical study of ideas in science education, concludes, 'When looked at in aggregate, the impact was impressive'. ${ }^{22}$ The new curricula not only provided science teachers with upto-date, science-based information, but also promoted hands-on, inquiry-based teaching techniques adhering to new ideas about children's learning processes. They added to the social status of science and technology that seemed to be prevalent at the time. Although many saw the curriculum reformers as one movement, the actual curricula differed in their practical scope and content. In addition, they were tied to opposite political agendas: the 'manpower gap' implied that science education should educate tomorrow's scientists and engineers, and therefore should emphasize disciplinary concepts and structure, while the 'science literacy deficit' had broader aims in mind, namely encouraging the entire population to become more informed about science and ultimately to think

19 For an exposition of these relations see also Robert K. Merton, 'The normative structure of science', in Merton, The Sociology of Science: Theoretical and Empirical Investigations, Chicago: The University of Chicago Press, 1973; first published 1942, pp. 267-278.

20 David Kaiser, 'Book review: Scientists in the Classroom: The Cold War Reconstruction of American Science Education', Science Education (2003) 87, pp. 911-913.

21 DeBoer, op. cit. (2), pp. 159-162.

22 DeBoer, op. cit. (2), p. 167. 
like scientists. These diverse ideological, practical and political implications of science education became entangled in global politics as UNESCO began to define its activities in the field.

\section{Science teaching at UNESCO before 1969}

Although UNESCO and its mandate for international cooperation in education, science and culture can be traced back to the League of Nations resolution of 21 September 1921, UNESCO only came into existence in the aftermath of the Second World War in 1945-1946, with biologist Julian Huxley as its first director-general. ${ }^{23}$ Science, or rather 'scientific', was included in UNESCO's charter only as a consequence of intense lobbying by scientists during the preliminary meetings and negotiations that occurred during the war. ${ }^{24}$ In the early years, UNESCO strove to define science, like culture and education, as a transnational and non-partisan activity. As a result, UNESCO in the early years viewed its role in the promotion of science, science policy and science education as a relatively passive one, with an emphasis on promoting international collaboration. However, the intensification of the Cold War during the 1950s and, more specifically, the admission of the Soviet Union and several of its Eastern bloc allies into UNESCO in 1954 resulted in UNESCO programmes increasingly focusing more on achieving specific goals. In the field of science policy, for example, UNESCO actively began to pursue the norm that science and technology should be promoted for the benefit of less developed countries and, consequently, that the planning of science policy, as well as science education, would be indispensable for all nation states. ${ }^{25}$

From 1950 onwards, science teaching featured explicitly in UNESCO's programme. ${ }^{26}$ Danish science journalist Børge Michelsen, who led UNESCO's Division for the Teaching and Dissemination of Science from 1948 to 1952, as a first step towards defining projects relevant to science teaching, established contacts with representatives of the National Science Teachers' Association in the United States. Based on their conversations, Michelsen concluded in a letter to Pierre Auger, head of UNESCO's Natural Sciences Department, that science teaching could have ideological implications in terms of preparing children for an open, tolerant and scientific world:

If we want the masses to think scientifically, work in that direction must be started while Mr. Johnson and Mrs. Patterson are little Johns and Joans. We must see to it that they leave their schools with the same open, inquiring, curious, experimenting minds as when they enter them, on their way through the schools doing our best to teach them logic and the methodic [sic] way of attacking problems, tolerance towards other beings and scepticism as to all kinds of

23 James P. Sewell, UNESCO and World Politics: Engaging in International Relations, Princeton, NJ: Princeton University Press, 1975.

24 Gail Archibald, 'How the "S" came to be in UNESCO', in Patrick Petitjean, Vladimir Zharov, Gisbert Glaser, Jacques Richardson, Bruno de Padirac and Gail Archibald (eds.), Sixty Years of Science at UNESCO, 1945-2005, Paris: UNESCO, 2006, pp. 36-40.

25 Martha Finnemore, 'International organizations as teachers of norms: the United Nation's Educational, Scientific, and Cultural Organization and science policy', International Organization (1993) 47, pp. 565-597.

26 UNESCO, 'UNESCO and science teaching', 15 April 1966, at http:/unesdoc.unesco.org/images/0018/ 001857/185707eb.pdf, accessed 14 November 2017. 
prejudice ... I know that the job of really doing something in this field will be a tough one, involving all kinds of problems from HOW TO PREPARE TEACHERS TO 'TEACH FOR THINKING' to 'WHAT SCIENCES ARE ESSENTIAL TO THE TRAINING OF A WORLD CITIZEN'. But I can hardly see how we can refuse to do the job without offending an influential body of NATSCIDEP.-sustainers $[$ sic $] .{ }^{27}$

Pierre Auger and Jean Piaget, first head of UNESCO's Education Department, seem to have taken Michelsen's advice when they recommended to the director-general that UNESCO should embark on a science education programme to determine 'the functions of science in adjusting man to the modern world with a view to guiding the teaching of science in primary and secondary schools'. ${ }^{28}$ As a first step, Auger and Piaget suggested commissioning ten leading scientists to prepare reports on the role of science in general education. Michelsen's division also initiated a series of inventories of apparatus and material for the teaching of science in primary, secondary and vocational schools, as well as universities and technical colleges. The model was based on information assembled regarding the teaching of science in the countries generally considered to be the leaders in the field - France, the Netherlands, Sweden, Switzerland, the United Kingdom and the United States. The series supplied information about science syllabuses at all educational levels and in many different languages. To address more specifically the situation in countries where the lack of educational equipment was found to be the most discouraging factor, UNESCO sponsored the publication by Oxford University Press of a series of ten manuals on science teaching in tropical countries, ranging from lessons in the rudiments of science to the higher grades of secondary education. ${ }^{29}$

UNESCO published its popular Source Book for Science Teaching in 1956 and in subsequent years had it translated into forty languages. ${ }^{30}$ The book became an international bestseller with 400,000 copies sold. It proved particularly useful to teachers in regions where there had previously been little or no equipment for practical science teaching. Practical initiatives to improve science teaching remained a key task for UNESCO in the years to come, while efforts to institutionalize and focus UNESCO's role in shaping and directing science teaching programmes in its member states became increasingly more important. ${ }^{31}$ In the late 1950 s and early 1960 s, the idea that socio-economic development and political independence would depend crucially on investments in education, as well as scientific and technical capacity building, began to catch on in many circles, including UNESCO. ${ }^{32}$ Economist Walt Rostow's influential 1960 model of economic stages of growth predicted that all societies would achieve high living standards if only they expanded their industrial base and allowed for social mobility by means of education. Four years later, human capital theory, developed by American

27 Børge Michelsen to Pierre Auger, 31 December 1948, UNESCO Archive, Paris (subsequently UA), file 5:37: Science Teaching - General, capitalization in original.

28 Pierre Auger and Jean Piaget to director-general, 26 October 1949, UA, file 5:37.

29 Marcel Florkin, 'Ten years of science at UNESCO', Impact of Science on Society (1956) 7, pp. 121-146.

30 UNESCO, Source Book for Science Teaching, Paris: UNESCO, 1956.

31 UNESCO, op. cit. (26), pp. 3-4.

32 Casper Andersen, 'Capacity building, scientific independence, and the development of UNESCO's science and technology agenda for Africa', Canadian Journal of African Studies (2017) 50, pp. 1-16. 
economists such as Gary S. Becker and Theodore Schultz, supplemented Rostow's theory by pointing out that education was an investment in human capital, and human capital was one of the main drivers of economic development. In what, during the early Cold War, became known as Third World countries, some interventions focused on strengthening scientific capabilities and building industry and infrastructure to stimulate the sort of development that meant 'becoming more like America' ${ }^{33}$ At UNESCO, the coupling of education with growth led to a shift in emphasis from 'fundamental education' as a basic human right to 'functional literacy' as the means to grasp technical knowledge and abstract scientific interpretations of phenomena, and thus, ultimately, as the prerequisite to advancement and progress. ${ }^{34}$

UNESCO's Natural Sciences Department abolished its Division for the Teaching and Dissemination of Science in 1957 and undertook steps to expand its programme for the promotion and teaching of science. ${ }^{35}$ In 1961, Albert Vinicio Baez, a physicist and the father of folk singers Joan Baez and Mimi Fariña, was invited to UNESCO to become the first director of the Division of Teaching of the Basic Sciences in Higher Education. Baez received his PhD in physics from Stanford University in 1950, around the time when Jerrold Zacharias became involved in Project Hartwell. Like other physicists in the early Cold War period, Baez's talents were in high demand. True to his pacifist and Quaker beliefs, however, he declined lucrative job offers in the military-industrial complex, believing that it was not the ultimate road to peace for a physicist to spend the rest of his life designing the operations of war. In 1958, Baez joined the PSSC, where he contributed to the preparation of instructional movies, teacher guides, standardized tests and recommendations for inexpensive laboratory equipment to use in conjunction with the PSSC Physics high-school textbook, which appeared in 1960. Baez stopped working for the PSSC in 1960, one year before he moved to Paris with his family to pursue his career at UNESCO. ${ }^{36}$

Baez arrived at UNESCO the year before the Natural Sciences Department launched its new aid programme for national scientific development. The programme rested on the idea that the basic natural sciences (mathematics, physics, chemistry, biology and geology) and their applications are essential to economic development and that they represent 'the most dynamic cultural force in the modern world' ${ }^{37}$ It also strongly promoted the basic claims of what later became human capital theory, namely that human resources were indispensable to all countries and were gravely in need of cultivation:

33 Odd A. Westad, The Global Cold War: Third World Interventions and the Making of Our Times, Cambridge and New York: Cambridge University Press, 2005, p. 111. See also Ozay Mehmet, Westernizing the Third World: The Eurocentricity of Economic Development Theories, London: Routledge, 1995.

34 Charles Dorn and Kristen Ghodsee, 'The Cold War politicization of literacy: communism, UNESCO, and the World Bank', Diplomatic History (2012) 36, pp. 373-398, 373; Jens Boel, 'UNESCO's Fundamental Education Program, 1946-1958: vision, actions and impact', in Poul Duedahl (ed.), A History of UNESCO: Global Actions and Impacts, New York: Palgrave Macmillan, 2016, pp. 153-167.

35 Anonymous, 'Teaching of science, Department of Natural Sciences', undated, UA, file 5:37.

36 Fernando Reimers, 'Albert Vinicio Baez and the promotion of science education in the developing world 1912-2007’, Prospects (2007) 37, pp. 369-381.

37 Natural Science Department of UNESCO, 'The role of science in the development of natural resources', Impact of Science on Society (1962) 12, pp. 213-229, 213. 


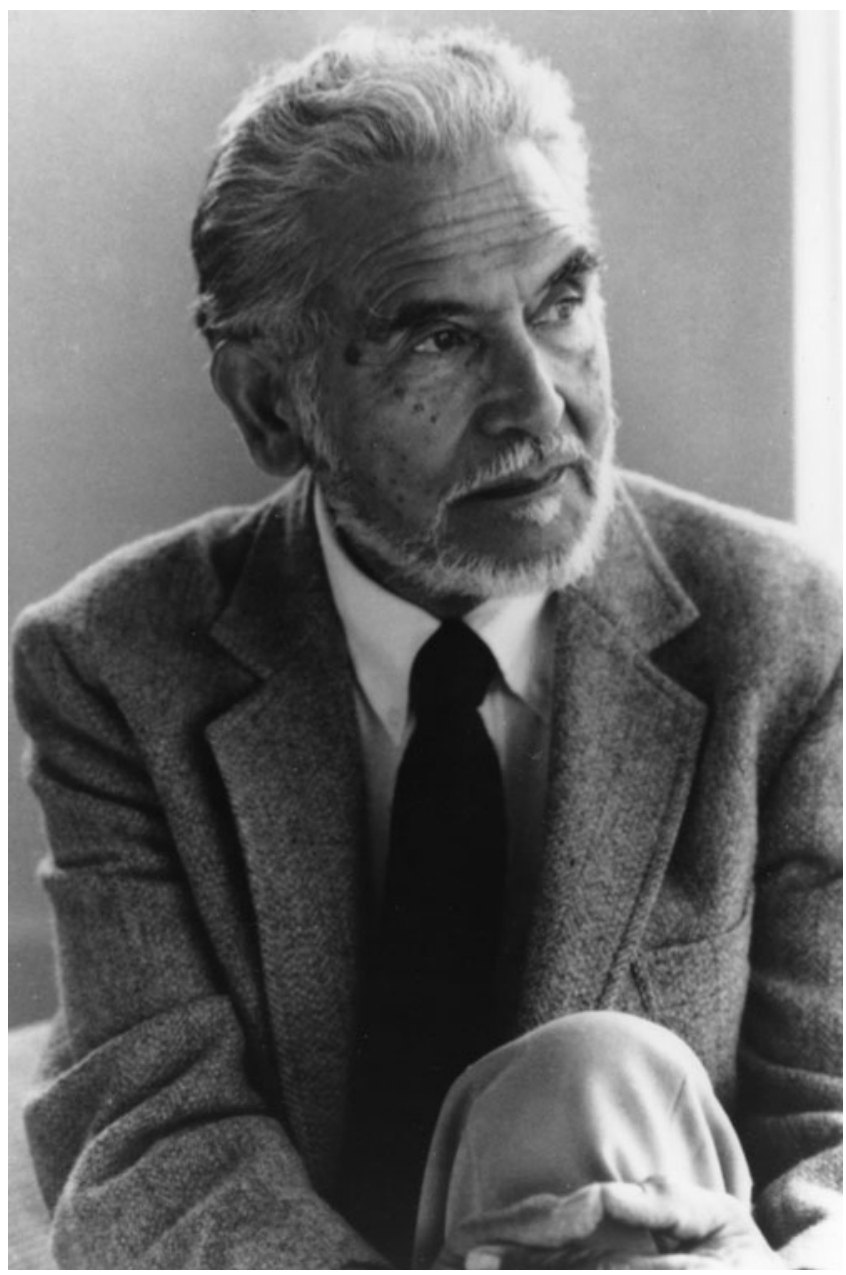

Figure 2. This image of Albert Baez, after his retirement, is from 1993. After he left UNESCO in 1963, Baez continued to work in the field of science education. He authored a textbook, The New College Physics: A Spiral Approach (1967), and made many educational physics films for the Encyclopaedia Britannica Educational Corp. Source: AIP Emilio Segrè Visual Archives, gift of Albert Baez.

Unusual talent in science must be sought out and nurtured because it is more precious than gold or uranium. Well-trained investigators of great talent and originality may be worth more to a country than the richest reserves of coal or oil, for without them the development of the country's reserves for its own profit is impossible. ${ }^{38}$

The programme focused on five different fields: (1) formulation of national science policy, (2) development of a scientific and technical workforce in order to overcome the shortage of trained scientists and engineers, (3) improvement of national research

38 Natural Science Department of UNESCO, op. cit. (37), p. 217. 
and development plans, (4) formulation and implementation of priority research programmes, and (5) improvement of the dissemination of scientific and technological information. Regarding the second point, UNESCO recommended that all countries should have comprehensive plans on science teaching from elementary school to higher education. UNESCO would assist the member countries in this regard by gathering, analysing and disseminating information about modern curricula and teaching methods, by stimulating the member countries to develop their own teaching materials and methods, and by upgrading teachers' qualifications through courses, fellowship programmes and international conferences. ${ }^{39}$ As a consequence of these ambitious plans for science teaching, UNESCO in 1965 merged Baez's division with the Division of Teaching of the Technological Sciences in Higher Education to form the Division of Science Teaching, with Baez as director. Whereas the teaching division in the Natural Sciences Department had previously been responsible for higher education alone, while the Education Department handled primary and secondary schools, the new division was charged with ensuring continuity in the teaching of the basic sciences at all levels. In the new division of responsibility, the Education Department would ensure the integration of science teaching with other subjects at each level.

Albert Baez was convinced, likely because of his involvement with the PSSC, that scientists should be leading forces in UNESCO's science teaching activities. The staff of Baez's own division comprised seven people, all with $\mathrm{PhDs}$ in the natural sciences. According to an internal document on UNESCO and science teaching, Baez and his co-workers would embark on a 'bold programme', undertaking 'a concerted worldwide effort for the development and modernization of science teaching'. ${ }^{40}$ The starting point for this undertaking was the 'revolution in science teaching' that had been achieved by curriculum reformers. Scientists with a specific field of specializations were crucial in this regard because they alone would be able to ensure that the curricula in the basic sciences were up to date and correct. Science and technology in other ways contributed to new possibilities in the field of science teaching. By means of a new and scientific approach to learning, the teaching would be more effective. New instructional tools, such as films, pre-programmed self-instructional devices, and take-home kits for laboratory work, also stemmed from the work of scientists and engineers. The next step would be to ensure that developing countries were able to take full advantage of the progress achieved in other countries, such as the United States. ${ }^{41}$

According to Baez, the role of UNESCO was to sponsor the development of such teaching aids, all of which should emphasize comprehension of basic principles, rather than memorization of facts, but also to conduct systematic evaluations of their applications. ${ }^{42}$ On a more general level, and fully in agreement with the ideology of the

39 Natural Science Department of UNESCO, 'Aid program to national scientific development', 5 April 1962, UA, file 5:37.

40 UNESCO, op. cit. (26), p. 3.

41 UNESCO, op. cit. (26), p. 3.

42 Albert V. Baez, 'New methods and techniques in education applied to the teaching of science in the programme of UNESCO', 5 October 1962, at http://unesdoc.unesco.org/images/0015/001546/154626eb. pdf, accessed 14 November 2017. 


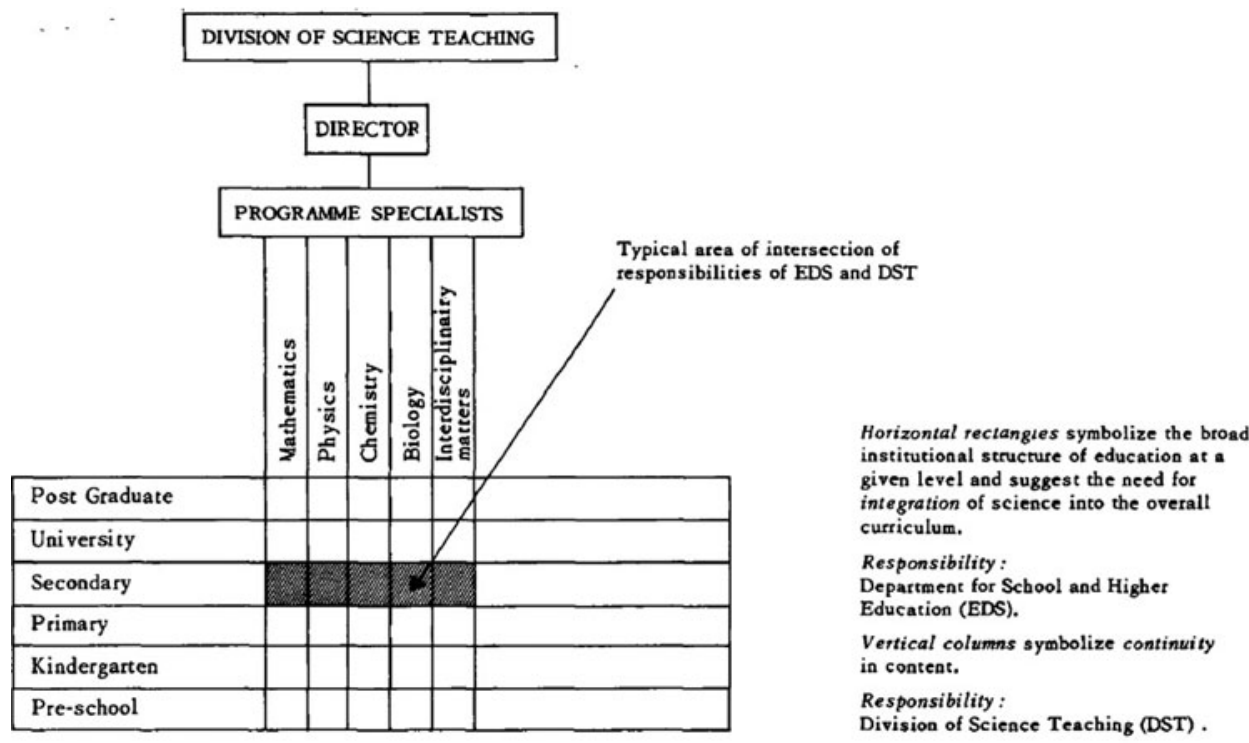

Figure 3. Function and structure of UNESCO's Division of Science Teaching, established in 1965. Source: UNESCO, 'UNESCO and Science Teaching', 15 April 1966, at http://unesdoc.unesco.org/ images/0018/001857/185707eb.pdf, accessed 14 November 2017.

American curriculum reformers, Baez proclaimed that science had made 'modern life physically more bearable and attractive' and had 'helped remove the ignorance and fear from the minds of men'. Consequently, it fell on UNESCO to encourage 'any nation that wants to derive the ultimate benefits from science' to create competent bodies for science and engineering education: 'A country without a significant number of high level scientists and engineers cannot be in the main stream of modern life'. ${ }^{43}$

\section{Integrated science teaching in theory and practice}

When Albert V. Baez resigned in 1967, the fundamental ideas of UNESCO's Division of Science Teaching already were well established. ${ }^{44}$ They generally built on the premise that investments in science education were of crucial importance, not only to socio-economic progress and development but also to the eradication of ignorance, superstition and oppression. Teaching basic science at all levels of the educational system thus would be essential to the development of human and natural resources in all countries, particularly those in the process of incipient modernization. States across the world ought to recognize this fact and take the steps necessary to institutionalize science education as an issue of government. Moreover, the notion of integration in relation to science teaching seems to have been introduced by one of Baez's employees, Robert

43 Albert V. Baez, 'The work of UNESCO in the field of higher scientific and technological education', 3 October 1962, at http://unesdoc.unesco.org/images/0015/001546/154627eb.pdf, accessed 14 November 2017.

44 UNESCO, op. cit. (26), p. 5. 
Ganeff, a Belgian chemist. Ganeff attended the UNESCO Frascati Meeting on 6-9 September 1965, where he met a number of science teaching delegates from various countries. In particular, the Yugoslavian delegation, led by a Professor Potkonjak, made an impression. Ganeff reported to Baez that, in Yugoslavia, science teaching was 'centered around the idea of integration of the sciences ... as well as a more fundamental integration of polytechnical education in the whole science curriculum'. ${ }^{45}$ The Yugoslavian approach, compared to the curriculum-reform approach that Baez and his fellow PSSC-ers had been promoting, focused more on the development of practical skills and less on science literacy for its own sake. Based on the archival sources, it is difficult to assess the actual impact of the Yugoslavian approach. It is noteworthy, however, that Ganeff's recommendation to render science teaching more oriented towards engineering and applied science occurred at exactly the same time as UNESCO adopted 'functional literacy' in its general educational programmes. ${ }^{46}$ As already mentioned, pursuing 'functional literacy' rather than 'fundamental education' had deep implications for UNESCO. In terms of educational policy, UNESCO no longer advocated literacy as a universal, humanitarian goal but rather as a means to economic development. For the United States, at least, promoting economic development equalled promoting capitalist market structures and combating communism. ${ }^{47}$

On 17 June 1969, when Stephen Oluwole Awokoya gave his opening address in Paris at the planning meeting for UNESCO's Programme in Integrated Science Teaching, he naturally was optimistic with respect to the future achievements of the programme. Awokoya stressed that most children in the developing regions of the world do not go beyond primary education, if they have any formal education at all. Introducing science to even the youngest schoolchildren and to pre-schoolers therefore was necessary, or they would miss it entirely. Integrated science, he argued, was well suited to this purpose for two reasons: first, primary-school pupils in developing countries need only learn the most basic scientific principles and need not be concerned with the subtler differences among, say, physics, biology and chemistry; second, teaching children to direct their natural-born curiosity into systematic inquiry and experimentation would allow them to learn things on their own:

The primary school child on coming to school has those interests which represent his potentialities as a future scientist. These interests should be the starting point of our integrated science approach ... These interests are our best allies in leading the child to explore nature and nature's ways. In his endeavour to find causes, he asks questions. In the past he was told to be quiet or given superstitious or untrue explanations. Today, he must be given scientific explanations and led to find out the answers by trial and error, by experiment and verification. There are the living roots from which scientific knowledge can grow. ${ }^{48}$

In his address, Awokoya argued that integrated science teaching should enable children to create something useful and to address actual problems in a meaningful manner by

45 Robert Ganeff to Albert Baez, 4 October 1965, UA, file 5:37.

46 Dorn and Ghodsee, op. cit. (34), p. 391.

47 Dorn and Ghodsee, op. cit. (34), p. 393.

48 Planning Meeting, op. cit. (1). 
means of technical solutions. Rather than focusing on abstract concepts, science teaching should help pupils to identify and solve basic challenges in food production, housing, health, clothing, communication, etc. This 'technological approach' would be vital to stimulating development in the recipient countries. In other words, science teaching in underdeveloped countries should not simply adopt curricula and teaching tools from developed countries, since they build on the implicit assumption that the socio-economic infrastructure and educational demands of the developing countries would be the same. Rather, science teaching should address actual and important sociocultural issues deemed relevant to particular communities. Awokoya suggested the following list of such issues: 'births, burials, betrothals and marriages, food production and harvest, ventilation and sleeping habits, care of the sick and their isolation in infectious cases, feeding customs and hygiene, water supply and disease'. ${ }^{49}$

The 'technological approach' to integrated science teaching went hand-in-glove with what Awokoya called the 'environmental approach'. He argued, 'wherever we may come from, whether from the East or the West, from the frigid or torrid zone, from the rainy forest or desert lands, science can and should always begin by a study of the environment that shapes our destiny'. ${ }^{50}$ All children liked to see the rainbow and seek explanations for it. However, differences remained. The parents of Swedish children would normally present them with scientific explanations for the colours of the rainbow and experiments pertaining to the wave nature of light. In contrast, the Nigerian child would learn that the rainbow is the excreta of the boa, and if one can find the place where the rainbow touches the ground, a little bit of its faecal matter can make one a millionaire. The environmental approach, Awokoya emphasized, had to tackle head-on such non-scientific beliefs, while also serving to give the children an exciting scientific adventure. The end goal really was to familiarize children with the Western approach to nature:

Belief systems which control learning are often markedly different in Western and non-Western cultures. For children living in societies which traditionally are non-scientific in the Western sense, faith in the capacity of man to discover and interpret the nature of the physical world and thereby to control it to his personal advantage may imply something of an intellectual and moral quantum leap. Without such a change, it is possible to acquire scientific knowledge and techniques, but such learning will represent nothing more than replacing one authoritarianism for another, with the new being no less sterile and inhibiting to intellectual development than the old. Sharpening the sense of curiosity of children in a manner that leads to their independent and intelligent thinking needs to be cultivated. Integrated science teaching was identified as being one of the most promising hopes of achieving such high aims. ${ }^{51}$

Although Awokoya had called for 'a sort of basic philosophy, if not a complete consensus as to what we are to do in basic science teaching', divergence with respect to what integrated science teaching really meant soon appeared. ${ }^{52}$ This divergence was partly an intended effect of UNESCO's programme, designed as it was to collect, disseminate

49 Awokoya, op. cit. (1), p. 19.

50 Awokoya, op. cit. (1), p. 19.

51 Awokoya, op. cit. (1), p. 18.

52 Awokoya, op. cit. (1), p. 19. 
and discuss information about integrated science teaching from all over the world. The programme included a series of international conferences, and six volumes of New Trends in Integrated Science Teaching (1971-1990) were published, together with regional contributions on the same theme. The breadth of integrated science was already prominent in the first volumes of the UNESCO series. A few examples from the realm of science teaching theory and practice, respectively, are provided in the following to demonstrate the types of discussion and activity that were pursued under the auspices of integrated science. All of the examples come from the first volume of the New Trends series.

James Rutherford and Marjorie Gardner, both affiliated with Harvard Project Physics, a national curriculum-development project to create a secondary-school physics education programme in the US, first approached the topic of integrated science from the perspective of the philosophy of science. ${ }^{53}$ They pointed out that most philosophers of science, indeed most scientists, would claim that science is not and cannot become unified', and that it is 'no longer widely believed that there is such a thing as the scientific method' ${ }^{54}$ Despite science from the viewpoint of the philosophy of science appearing to be highly disunified - 'there seems to be a variety of methods used by different scientists in different fields at different times', they wrote - Rutherford and Gardner still maintained that pursuing integrated science teaching was valuable. However, rationales other than reference to the fundamental nature of science had to be suggested to buttress the case for integrated science. Curriculum developers and science teachers instead had to consider the students' or pupils' needs, as they designed and applied their integrated science teaching methods and curricula. From this perspective, Rutherford and Gardner concluded, integrated science teaching was certainly a useful approach in that it prepared children for coping with the world that they encounter - a world that, for most children, indeed most people, is characterized by a high degree of unity.

Other contributors to the first volume of New Trends in Integrated Science Teaching were less hesitant than Rutherford and Gardner to see science as a more or less unified and coherent whole at the levels of method and process. For example, Robert Francis and Hubert M. Dyasi, both of the Science Curriculum Development Centre at Njala University in Freetown, Sierra Leone, stated, 'In its process, science uses logic to build up an organized and tested body of knowledge on which to draw for further investigations of nature'. ${ }^{55}$ The American Association for the Advancement of Science, in its contribution, extracts from the booklet Science: A Process Approach, depicted science as a collection of scientific behaviours: 'Scientists do observe, and classify, and measure, and

53 James Rutherford and Marjorie Gardner, 'Integrated science teaching', in Peter E. Richmond (ed.), New Trends in Integrated Science Teaching, vol. 1, Paris: UNESCO, 1971, pp. 47-55, at http://unesdoc.unesco.org/ images/0013/001365/136594mb.pdf, accessed 14 November 2017.

54 Rutherford and Gardner, op. cit. (53), p. 49, underlining in original.

55 Robert Francis and H.M. Dyasi, 'A case study on integrated science teaching', in Richmond, op. cit. (53), pp. 97-105, 99, at http://unesdoc.unesco.org/images/0013/001365/136594mb.pdf, accessed 14 November 2017. 
infer, and make hypotheses, and perform experiments'. ${ }^{56}$ Integrated science teaching, according to this approach, would facilitate children's adaptation of such behaviours to develop their intellectual skills and human capabilities. The same basic philosophy inspired many other projects, such as the Indian Science Learning through Inquiry, prepared by the Community Science Centre at Ahmedabad, which aimed to provide children with 'a glimpse of how a scientist works and how a scientist is able to recognise the accurate nature of things by observation, hypothesis, experimentation, conclusions, and predictions'. ${ }^{57}$

Others again accentuated the unifying conceptual structure of science as a focal point for integrated science teaching. Morris Shamos, who much later expounded the view that only those seeking careers in science should have to wrestle with a full scientific curriculum, presented the Conceptually Oriented Program in Elementary Science (COPES) for kindergarten to sixth grade. ${ }^{58}$ COPES aimed at focusing the attention of children on the 'great ideas' in science, i.e. 'the broad, inclusive conceptual schemes in terms of which we seek to account for the familiar facts of nature'. ${ }^{99}$ The five conceptual schemes included in COPES were:

1 The structural units of the universe (from atoms and molecules to stars and galaxies);

2 Interaction and change (from chemical reactions to geological events);

3 Energy conservation;

4 Energy degradation; and

5 The statistical view of nature (Brownian motion, Mendelian laws, etc.).

Recognizing the difficulty of identifying great scientific ideas that would fully express the views of all scientists and all science educators, Shamos nevertheless proposed that the conceptual-schemes approach would assist children in developing an understanding of 'the nature of matter' at different levels of sophistication. Having such a definite objective, he claimed, would not only provide teachers and children with a clearly defined goal, but also, more importantly, give 'them a cohesive picture of science rather than a series of disjointed topics'.60

Whereas the above contributions presented philosophical reflections about the nature of science and/or the nature of nature, others were concerned with the integration of integrated science teaching and social issues. The Tel Aviv Elementary Science Teaching Project, for example, adapted the new integrated science teaching approaches to

56 American Association for the Advancement of Science, Science: A Process Approach, in Richmond, op. cit. (53), pp. 172-178, at http://unesdoc.unesco.org/images/0013/001365/136594mb.pdf, accessed 14 November 2017.

57 Community Science Centre, 'Science learning through inquiry', in Richmond, op. cit. (53), pp. 207-217, at http://unesdoc.unesco.org/images/0013/001365/136594mb.pdf, accessed 14 November 2017.

58 Morris H. Shamos, 'The conceptually oriented program in elementary science', in Richmond, op. cit. (53), pp. 179-187, at http://unesdoc.unesco.org/images/0013/001365/136594mb.pdf, accessed 14 November 2017. Shamos's later critique of scientific literacy is Shamos, The Myth of Scientific Literacy, New Brunswick, NJ: Rutgers University Press, 1995.

59 Shamos, 'The conceptually oriented program', op. cit. (58), p. 180.

60 Shamos, 'The conceptually oriented program', op. cit. (58), p. 181. 
schools in Israel for the sake of educating 'citizens out of an ultra-heterogeneous population'. ${ }^{61}$ Encouraging the development of systematic thinking and adjustment to 'a modern pattern of life', science teaching would have general importance for the establishment of a modern nation state based on scientific rationality and modern technology. A large population of Israeli children were 'culturally deprived', as the authors, Meir Feuchtwanger and Eugene Kaplan of Tel Aviv University, put it. ${ }^{62}$ These children were particularly in need of scientific knowledge and methods of acquiring such knowledge. The teaching project, much like the project of the American Association for the Advancement of Science described above, therefore aimed at behavioural change. One of its teaching units, called 'Things we require for good health', aimed not to teach facts about bacteria but rather to familiarize the children with scientific behaviours, such as observation, prediction, classification and experimentation. Ultimately, the unit aimed to prepare the children to honour the basic rules of hygiene, such as washing one's hands and brushing one's teeth, while also instilling a sense of scientific reasoning in them.

'Ask the ant lion' was the name of a science teaching unit developed and tested in the course of the African Primary Science Program, funded and organized by the Educational Development Center in Newton, Massachusetts. ${ }^{63}$ The unit exemplified the environmental approach in integrated science teaching that Stephen Oluwole Awokoya had propounded in his opening address in 1969. Ant lions are small predatory larvae that eat arthropods, mainly ants. They build small funnel-shaped sandpit traps to capture ants and other insects. The 'Ask the ant lion' teaching unit was taught at Ukonga Primary School, close to Dar es Salaam, where the children already knew ant lions but not much about them. The unit required the children to become more acquainted with ant lions by asking questions. 'If you have a problem', the general theme ran, 'ask the ant lion': How do you move? Where do you live? How do you make your pit? Why do you make your pit the way you do? And so on. The instructor, Joseph Elstgeest, remarked that people, upon hearing about the ant lion unit, would often smile benignly, expressing their conviction that an unimportant, low, stupid little ground-dwelling insect like the ant lion could not possibly be a proper object of science instruction in the schools. What does it accomplish? What is the use? His reply was the following:

My strongest and only argument is a class of children, busily engaged in experimentation with ant lions; their eager questions, their attempts to find answers to their problems, their growing satisfaction at being able to ask the ant lion, and their growing realization that they do get the answers without being told, but through their own efforts. And, if the argument is still not settled, look for the teacher. Often you have to search for him among his children, as engrossed in their investigation as they are. ${ }^{64}$

61 Meir Feuchtwanger and Eugene Kaplan, 'The Tel Aviv Elementary Science Teaching Project', in Richmond, op. cit. (53), pp. 116-126, at http://unesdoc.unesco.org/images/0013/001365/136594mb.pdf, accessed 14 November 2017.

62 Feuchtwanger and Kaplan, op. cit. (61), p. 120.

63 Joseph Elstgeest, 'Ask the ant lion: the growth of an African primary science unit', in Richmond, op. cit. (53), pp. 136-143, at http://unesdoc.unesco.org/images/0013/001365/136594mb.pdf, accessed 14 November 2017

64 Elstgeest, op. cit. (63), p. 143. 
One of the conclusions of the African Primary Science Program was that there was no shortage of interesting science teaching units and new teaching tools. ${ }^{65}$ Rather, good teachers and people with experience and expertise in continuous curriculum renewal were in demand. Also, evaluating the outcomes of the many initiatives in terms of student achievement proved to be demanding in terms of human and financial resources. Thus more efficient, standardized evaluation schemes were called for. These conclusions seemed also to have been reached by the people involved in UNESCO's Programme in Integrated Science Teaching, as the subsequent volumes in the New Trends series were dedicated to the education of teachers and to evaluation. ${ }^{66}$ It is beyond the scope of this paper to delve more into these particular issues; it suffices to say that the diversity of approaches to teacher education and student evaluation was as high as the diversity of approaches to integrated science teaching itself, as witnessed by the examples drawn from Volume 1 above.

\section{Trends in integrated science teaching}

By the time of publication of the fifth volume of New Trends in Integrated Science Teaching in 1979, the time seemed ripe for reflection on what had been achieved thus far. ${ }^{67}$ The volume was based on the proceedings of an international conference organized in April 1978 at the University of Nijmegen in the Netherlands, approximately ten years after the conference in Varna (Droujba), Bulgaria, that had originally spurred the initiation of UNESCO's programme. ${ }^{68}$ Several surveys of existing integrated science curricula and different strategies for implementing integrated science teaching in schools resulted from the Nijmegen conference, some of which are treated here.

Sheila Haggis and Philip Adey, respectively of UNESCO's Division of Science Education and the Centre for Science, Chelsea College, London, in their review of integrated science education, analysed information about some 130 curricula. These curricula had all been published or were intended to be published, and they had been tried out in actual classrooms before (intended) publication. ${ }^{69}$ Most of the science curricula had

65 E. Ayotunde Yoloye, 'Evaluation of the African Primary School Program', 24 November 1975, at http:// unesdoc.unesco.org/images/0002/000206/020641EB.pdf, accessed 14 November 2017. See also Sam T. Bajah, 'Primary science curriculum development in Africa: strategies, problems and prospects with particular reference to the African Primary Science Programme', European Journal of Science Education (1981) 3, pp. 259-269.

66 David Cohen (ed.), New Trends in Integrated Science Teaching, vol. 4, Evaluation of Integrated Science Education, Paris: UNESCO, 1977, at http://unesdoc.unesco.org/images/0013/001366/136659eo.pdf, accessed 14 November 2017; Peter E. Richmond (ed.), New Trends in Integrated Science, vol. 2, Paris: UNESCO, 1973, at http://unesdoc.unesco.org/images/0013/001365/136595eo.pdf, accessed 14 November 2017; Richmond (ed.), New Trends in Integrated Science Teaching, vol. 3, Education of Teachers, Paris: UNESCO, 1974, at http://files.eric.ed.gov/fulltext/ED106106.pdf, accessed 14 November 2017.

67 Judith Reay (ed.), New Trends in Integrated Science Teaching, vol. 5, Paris: UNESCO,1979, at http:// unesdoc.unesco.org/images/0013/001366/136669eo.pdf, accessed 14 November 2017.

68 UNESCO, 'Congress on the integration of science teaching, Droujba (Bulgaria), 11-19 September 1968', September 1968, at http://files.eric.ed.gov/fulltext/ED030578.pdf, accessed 14 November 2017.

69 Sheila Haggis and Philip Adey, 'A review of integrated science education worldwide', in Reay, op. cit. (67), pp. 35-39, at http://unesdoc.unesco.org/images/0013/001366/136669eo.pdf, accessed 14 November 2017. 
been designed for primary and junior secondary schools, and most were assessed as being partially or totally integrated in the sense that very little or no disciplinary differentiation in the range of topics and teaching methods could be discerned. The focus on primary and junior secondary schools, the authors wrote, reflected the awareness that had developed in most countries that science should form part of the general education of all citizens. The majority of the courses designed for use in primaryschool curricula were based on direct pupil experience with concrete material. Like the 'Ask the ant lion' unit described above, these courses emphasized observation, inquiry and exploration of local environments. They also indicated a major shift in the role of the teacher from purveyor of information to facilitator and participant in learning processes - recall Elstgeest's description of the teacher being as engaged in ant lions as the children. This change in role, Haggis and Adey concluded, posed a serious problem to effectively introducing integrated science courses into primary education and enhanced the need for teacher training.

Wynne Harlen, who later became professor of science education at Liverpool University, pointed out in her contribution some of the strengths and weaknesses of implementing integrated science courses in primary schools. ${ }^{70}$ The central issue, she stated, was how to balance the emphasis on content, i.e. the facts, principles and concepts that help children in understanding their environment, and the emphasis on the skills and behaviours that children use to learn something. Primary-school teachers emphasizing content might find themselves challenged over the amount of factual science knowledge required, while teachers applying the inquiry-based and childfocused model would need to rethink their roles as teachers. One of the major obstacles to integrated science courses appearing at all in school curricula, Harlen said, was the lack of external motivation in the form of centrally imposed syllabuses. Even if prepared material was available and the teacher had incentives to adopt it, it often turned out that 'teacher's guides are used as recipe books and teachers soon begin to leave out pupil activities, returning to a lecture and demonstration style of teaching. ${ }^{71}$ Simply disseminating teaching materials, such as guides, kits of equipment, films and other audiovisual aids, from centres of development (typically developed countries) to users in 'peripheral', less developed regions had proved to be an ineffective strategy for implementing integrated science teaching. Harlen instead proposed the creation of local centres to ensure that science was integrated into curricula and to provide long-term support for teachers at the regional and national levels.

A group of authors looked for trends in the instructional objectives and integrating techniques of integrated science courses. ${ }^{72}$ Like Haggis and Adey, they surveyed far more than a hundred courses and discovered a huge breadth. Some courses aimed at developing different kinds of scientific literacy in children: from understanding the

70 Wynne Harlen, 'Towards the implementation of science at the primary level', in Reay, op. cit. (67), pp. 59-67, at http://unesdoc.unesco.org/images/0013/001366/136669eo.pdf, accessed 14 November 2017.

71 Harlen, op. cit. (70), p. 63.

72 Thomas Gadsden, Paul Beclit and George Dawson, 'The design and content of integrated science courses', in Reay, op. cit. (67), pp. 40-50, at http://unesdoc.unesco.org/images/0013/001366/136669eo.pdf, accessed 14 November 2017. 
conceptual basis of science to acquiring the manipulative skills of scientists or simply valuing science as a cultural achievement. Other courses pursued personal growth, developing confidence in independent inquiry and knowledge applicable to many different situations. Others again concentrated on socially relevant issues to contribute to the improvement of one's life and one's community. With respect to techniques for selecting and integrating different types of content, diversity also was evident. Some courses adopted a scientific perspective, using science content or methods as guidelines for the organization of content; others started with more practical or personal considerations about what the course ought to achieve. The diversity notwithstanding, the authors concluded,

Just as there has been a trend toward a rapid increase in the number of integrated science programmes existing worldwide, there have also been very distinct positive trends in the changing character of these programmes. In general, the trends seem to indicate a greater focus on the importance of the learner and a greater understanding of the nature of science as an integrated whole. Trends are seen toward increasing relevance, greater attention to the needs of special groups of students, more and broader objectives (especially affective ones), tying science more closely to society, more complete and creative integration, and increased flexibility in programme design. One especially important trend is the greater attention paid to research and theory on how children learn. ${ }^{73}$

Partly due to the lessons learned in the course of the programme for integrated science teaching, UNESCO, from the beginning of the 1980s onwards, began placing more emphasis on the application of science and technology education to the needs of daily life and the development of society. This was exactly what Stephen Oluwole Awokoya promoted in 1969 at the launch of UNESCO's Programme in Integrated Science Teaching, when he spoke about the 'technological approach' and the 'environmental approach'. The programme in some ways had served to 'export' some of the basic ideas about, and political understandings of, the role of science that emerged in the United States during the course of curriculum reforms in the early Cold War. Although curriculum reformers did not represent a unified movement, we can distil some basic ideas: curriculum development should involve working scientists; good science teaching would encourage more children to embark on careers in science and engineering and would promote science literacy for all; and science education was a means to improve the human capital of any nation. The programme, however, did much more than simply transport such ideas from the United States to countries around the world. It also broadened the very notion of science teaching, allowing it to encompass curricula and teaching methods developed by non-scientists that did not particularly aim at teaching science but rather at changing children's attitudes and approaches.

\section{Disintegrating integrated science teaching}

UNESCO's Programme in Integrated Science Teaching ran from 1969 to 1990. It extended the 'revolution in science teaching' that had emerged in the United States

73 Gadsden, Beclit and Dawson, op. cit. (72). p. 48. 
during the early Cold War into the developing countries. UNESCO adapted prevailing ideas about science teaching, originally seen as a means to filling the 'manpower gap' and overcoming the perceived 'science literacy deficit', to its task of building human resources in the developing countries - what economists such as Frederick Harbison called the 'ultimate basis for the wealth of nations'. ${ }^{74}$ Whereas American curriculum reformers, many working and renowned scientists, emphasized disciplinary concepts and structure, as well as scientific methods, UNESCO's programme promoted an integrated approach to science teaching. From the outset, integrated science teaching was an ambitious and ambiguous idea. For the most part, it entailed less focus on scientific disciplines and scientific method strictly defined and more on teaching children how to adopt (or rather maintain, for the basic assumption was that children were born naturally curious and were experimentalist engineers) a curious, experimental and engineering approach in life. This approach would not only develop the children's own human resources to the benefit of the nation, but also prepare them mentally and ideologically for progress and, indeed, modern life itself.

During the Cold War, science education became part of diverse ideological and political agendas. In the United States, curriculum reforms initiated by groups such as the PSSC were firmly embedded in Cold War politics. ${ }^{75}$ The general mobilization of science and technology for national competitiveness and national security gave new importance to science education. Science education was the primary means of ensuring the scientific and engineering workforce of the future. Some maintained that science education was a bulwark against irrational social forces, whether McCarthyism, communism or just plain anti-elitism. As other countries and international organizations also began taking an interest in science education, to some extent inspired by American developments, the ideological and political bearings of science education changed or broadened. For UNESCO, science education was mainly a means of mobilizing human resources in the developing countries to encourage modernization and political independence by way of socio-economic growth. Since most children in the developing countries would not receive education beyond primary school, this part of the world was where the main efforts would have to be exerted.

UNESCO's Programme in Integrated Science Teaching in many ways responded to the demands placed on science teaching in the context of development: the importance attached to science as a unified approach to nature (in contrast to a specialized approach); to social, technical and environmental issues in the child's immediate surroundings; and to experimental and inquiry-based thinking and learning. Despite some agreement with respect to the overall aims of the programme, there were many different and not wholly compatible means of implementing integrated science teaching in practice. Nor did teachers, scientists and evaluators always agree regarding the value of the basic ideas of integrated science teaching. As David Cohen noted in his introduction to the fourth volume of the New Trends in Integrated Science Teaching series addressing

74 Quoted in Dennis A. Rondinelli, John Middleton and Adriaan M. Verspoor, Planning Education Reforms in Developing Countries: A Contingency Approach, Durham, NC: Duke University Press, 1990 , p. 4. 75 Rudolph, op. cit. (2). 
the evaluation of integrated science teaching, 'In summary, consensus is lacking concerning the "pros" and "cons" of the study of science as comprising "separate subjects", or as "integrated science". ${ }^{76}$

The disagreement ran even deeper than Cohen surmised and pertained to the core of integrated science and science itself. Some would argue that integrated science teaching reflected the fundamental unity of science and nature; others acknowledged that science was highly heterogeneous, exactly like the environments in which children live, composed of natural and cultural entities. Some believed that integrated science teaching should aim at preparing children for modern life by way of enculturating them into the world of scientific rationality and contemporary technologies. Others were more concerned about their personal skills. Still others again drew close connections between integrated science teaching and scientific literacy. Some integrated science teaching units addressed natural phenomena and were less concerned with scientific explanations; others used integrated science as a means to combine two or three closely related disciplines. Most often, all of these different ideas and practices seemed to coexist in an unproblematic manner, but there were also attempts to differentiate conceptually between different meanings of, and arguments for, integrated science. ${ }^{77}$

As the Cold War was ending, UNESCO's Programme in Integrated Science Teaching lost its impetus. Already in 1974, the main goal of UNESCO's campaign to promote functional literacy in the developing countries, i.e. the creation of skilled and informed citizens, had been criticized for primarily advancing the interests of the Western countries. Frustrated members, such as Vietnam, Algeria and Brazil, argued that UNESCO suffered from attempts on the part of the United States to undermine the humanitarian goals of worldwide literacy. Director-General Amadou-Mahtar M'Bow agreed. He and others questioned the basic assumption, arguing that development would not result from an increase in human capital and economic growth, but required fundamental changes in the prevailing world economic system dominated by the United States. Ten years later, the United States left UNESCO, stating that it had become excessively politicized by left-wing forces. ${ }^{78}$ UNESCO's Programme in Integrated Science Teaching was limited in scope compared to its general literacy campaign, and it was not, to my knowledge, subject to the same kind of criticism. Rather, UNESCO succeeded in sustaining the programme, which built on Western beliefs in the relationships among science education, human capital and economic growth, for more than two decades, when large countries, such as the United States and the United Kingdom, criticized the organization for its anti-Western sentiments. This persistence testifies to the durability and flexibility of the very notion of integrated science teaching.

76 David Cohen, 'Evaluation in integrated science teaching: an introduction', in Cohen, op. cit. (66), pp. 9-15, at http://unesdoc.unesco.org/images/0013/001366/136659eo.pdf, accessed 14 November 2017.

77 Sally A. Brown, 'A review of the meanings of, and arguments for, integrated science', Studies in Science Education (1977) 4, pp. 31-62.

78 Dorn and Ghodsee, op. cit. (34), pp. 396-397. 